\title{
Technè
}

La science au service de l'histoire de l'art et de la préservation des biens culturels

43 | 2016

Une Europe de la recherche en sciences du patrimoine

\section{Technological studies on Bronze Age metal body armour: from the Aegean to Western Europe}

Recherches technologiques sur les armures métalliques de l'âge du Bronze, de la mer Égée à l'Europe occidentale

\section{Marianne Mödlinger}

\section{(2) OpenEdition}

\section{Journals}

Electronic version

URL: http://journals.openedition.org/techne/792

DOI: $10.4000 /$ techne.792

ISSN: 2534-5168

\section{Publisher}

C2RMF

\section{Printed version}

Date of publication: 1 August 2016

Number of pages: $90-93$

ISBN: 978-2-7118-6338-9

ISSN: 1254-7867

Electronic reference

Marianne Mödlinger, « Technological studies on Bronze Age metal body armour: from the Aegean to Western Europe ", Technè [Online], 43 | 2016, Online since 19 December 2019, connection on 23 July 2020. URL : http://journals.openedition.org/techne/792 ; DOI : https://doi.org/10.4000/techne.792

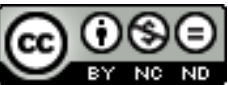

La revue Technè. La science au service de l'histoire de l'art et de la préservation des biens culturels est mise à disposition selon les termes de la Licence Creative Commons Attribution - Pas d'Utilisation Commerciale - Pas de Modification 4.0 International. 


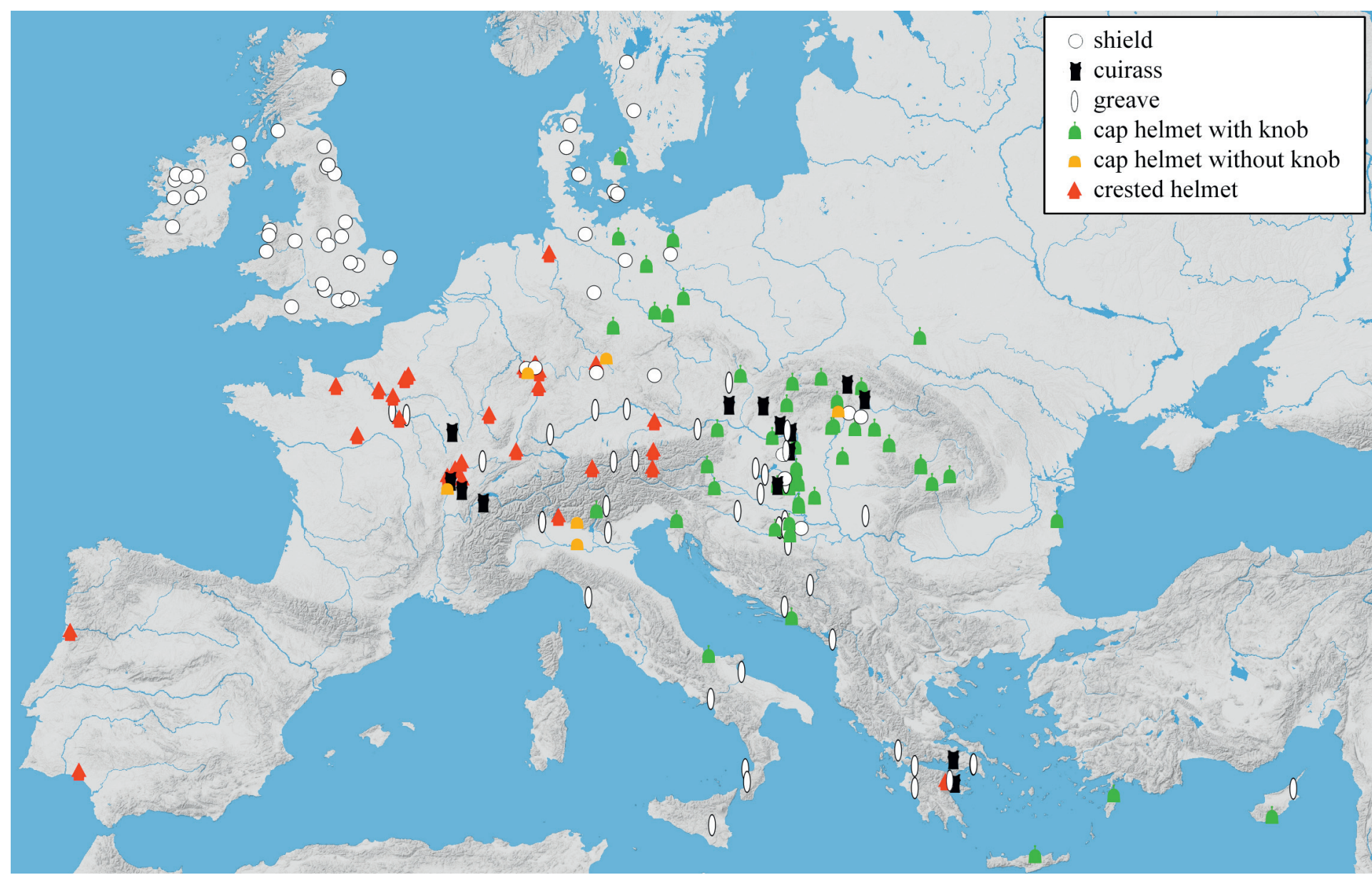

Fig. 1. Find spots of Bronze Age metal armour in Europe. 
Marianne Mödlinger

\section{Technological studies on Bronze Age metal body armour: from the Aegean to Western Europe}

Recherches technologiques sur les armures métalliques de l'âge du Bronze, de la mer Égée à l'Europe occidentale

Abstract. European Bronze Age metal armour, that is helmet, cuirass, shield and greaves is considered as one of the peaks of Bronze Age metal work. Within recent projects funded by the Austrian FWF and the European Union within FP7, most of the European Bronze Age body armour could be studied in detail, including chemical and metallographic analyses, analyses of manufacture and usage of the armour, combined with a conventional archaeological study (typology, distribution, development of the armour).

Keywords. European Bronze Age, metal body armour, manufacture, usage, chemical composition.
Résumé. Les armures métalliques, avec casque, cuirasse, bouclier et jambières, représentent un des sommets de la métallurgie à l'âge du Bronze. Dans le cadre de projets récents financés par le Fonds autrichien pour la science et par le septième programme-cadre (7 PC) de l'Union européenne, nous avons pu procéder à des recherches approfondies sur les armures de l'âge du Bronze européen, comprenant des analyses chimiques et métallographiques, ainsi qu'une étude de la fabrication et de l'utilisation des armures, en conjonction avec une enquête archéologique classique (typologie, répartition, évolution de l'armure).

Mots-clés. Âge du Bronze européen, armure métallique, fabrication, utilisation, composition chimique.
The first European metal body armour is known from Dendra, Greece, around 1400 BC. The Dendra grave contained a whole set of armour: a boar tusk helmet with bronze cheek plates, a full-body bronze panoply (fig. 2a), greaves, an arm protection, and most likely also a shield made of organic material. The chronological next finds of body armour are known from the Carpathian Basin, and date to the beginning of the Late Bronze Age (c. 1250 BC). Types of Carpathian body armour were also found in Western Europe, where they triggered the production of new local types. The development of metal defensive armour out of organic material precursors can be seen as a response to the growing effectiveness of offensive weapons such as sword and spear.

Today, we know roughly 30 cuirasses, 50 Western European helmets, 70 Eastern European helmets and 75 greaves. These numbers are, compared to the thousands of contemporary bronze swords, spears and daggers, astonishing low. This can be explained by local recycling and deposition habits, but also by the usage of organic body protection, which is rarely preserved.

The wide distribution of Bronze Age armour (fig. 1), now kept in various museums all across Europe, makes it difficult to study all armour in detail, and to compare the single objects with each other in terms of chemical composition, manufacture and usage. The author was able to study most Eastern European body armour, but sought to study as well the Western European armour, that is to say the armour stored in Western European museums. CHARISMA offered here the perfect opportunity not only to study the armour itself (as happened during an Archlab at the British Museum), or to analyse it (two times Fixlab at the Budapest Neutron Centre), but also to get valuable insight into the whole documentation of the metal body armour in French museums (Archlab at the C2RMF Paris).

At the C2RMF, the Archlab-stay permitted the author to collect valuable data in order to compare Western and Eastern European armour: access to restoration protocols, the documentation of the find circumstances and excavations, analytical data (chemical analyses, metallographic studies) and literature not available elsewhere. Photos and radiographies of the armour concerned were provided. Discussions with colleagues in charge of analyses of Western European Bronze Age helmets e.g. from Bernières D'Ailly had a big impact for comparing production techniques and alloys used for the manufacture of Western and Eastern European helmets. Moreover, the author also studied the armour itself: several cuirasses and helmets could be studied directly in the museums were they are exposed, and traces of manufacture, repair and usage were detected. 


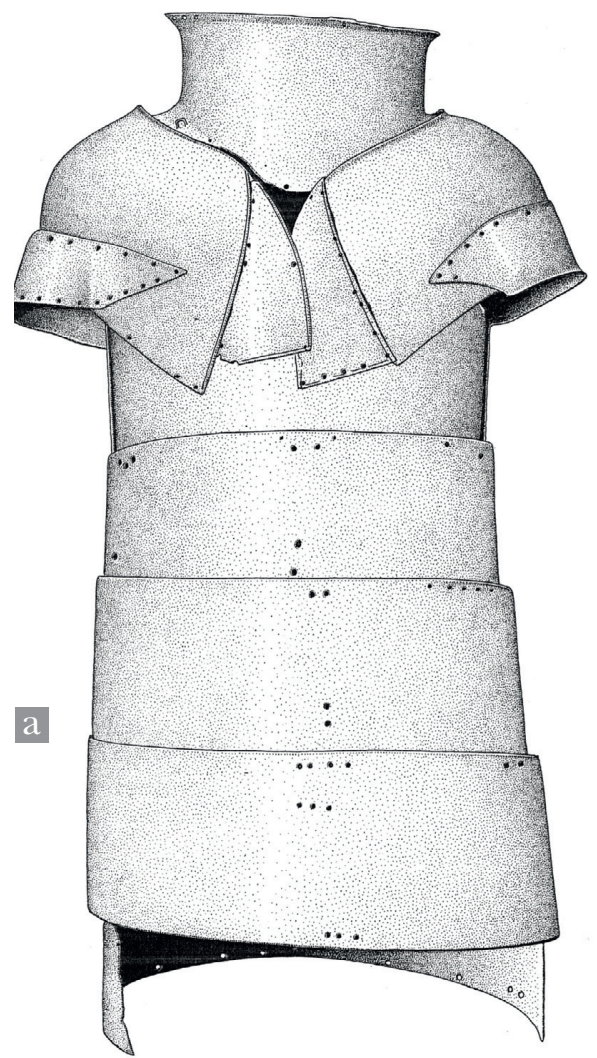

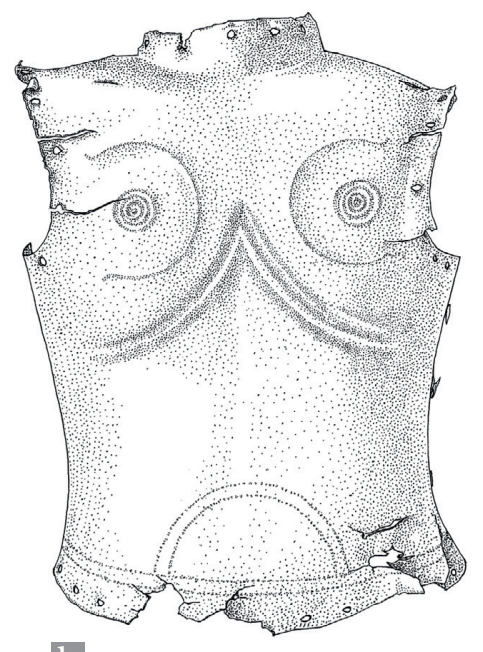

b

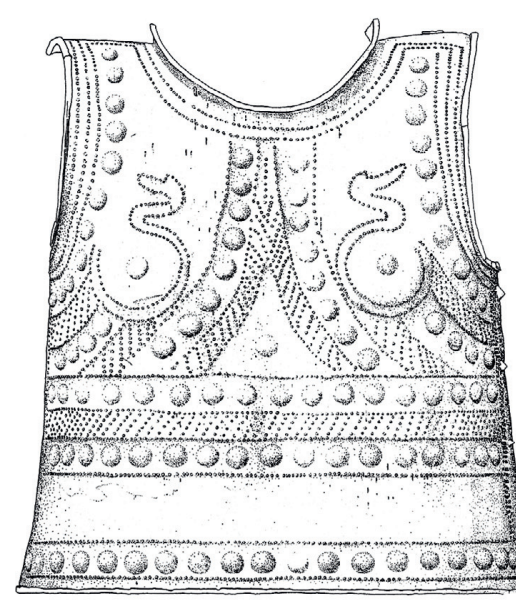

C

Fig. 2. Different types of Bronze Age cuirasses (no scale). a) Greek cuirass (Dendra, Greece, grave 12; after Müller-Karpe 1980). b) Carpathian cuirass (from the Danube at Pilismarót, Hungary; after Petres et al. 2014).

c) Western European cuirass (Fillinges, Frankreich; after Mottier 1988).
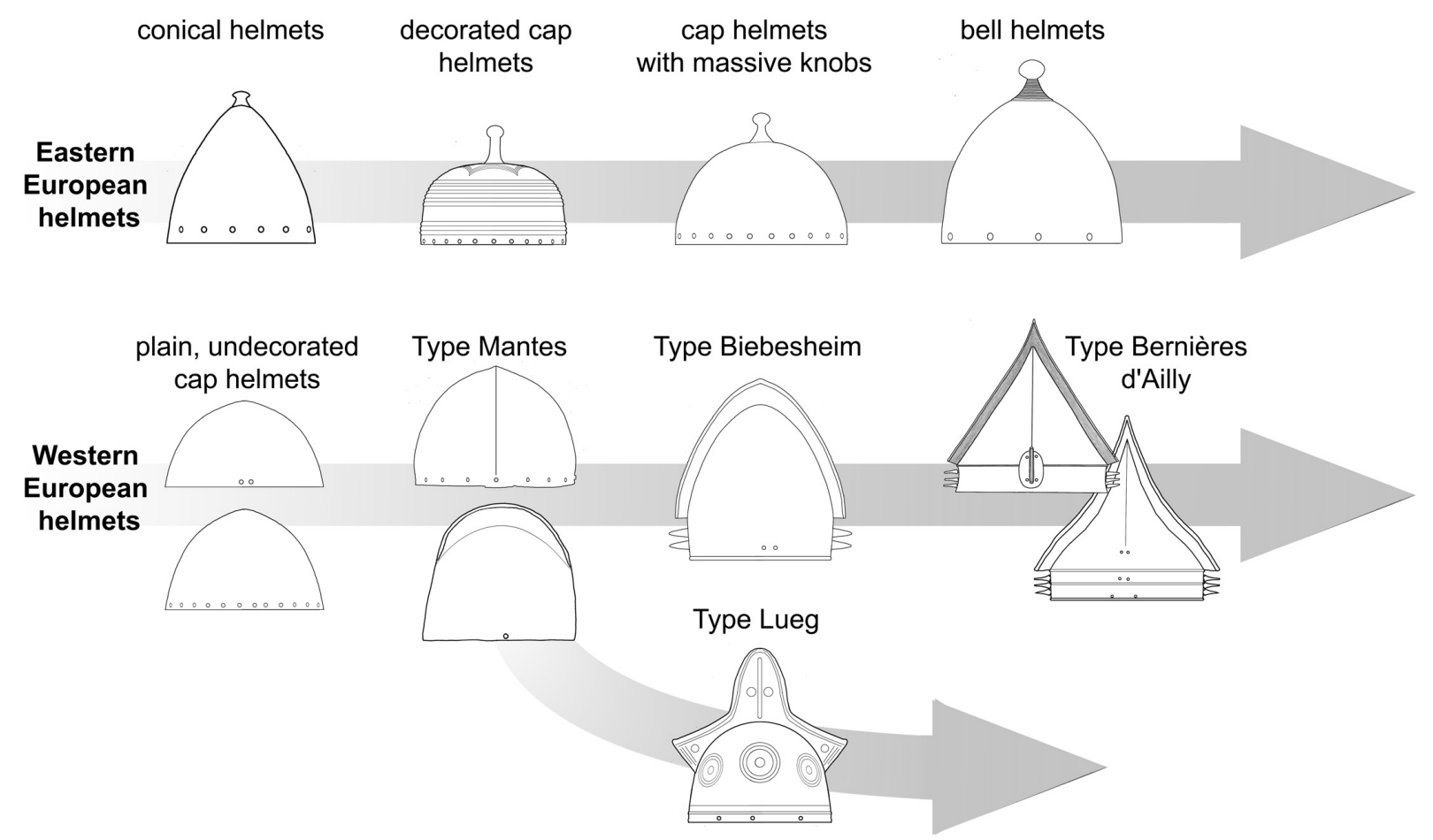

Fig. 3. Development of Bronze Age helmets in Western and Eastern Europe. 
As compared with Greek cuirasses and those from the Carpathian Basin, Western European cuirasses are rich in terms of evidence of repairs (fig. 2). These repairs are either the result of injuries during combat or manufacturing mistakes. Nevertheless, only one of the Western European cuirasses still shows damage caused by a bronze weapon. The cuirass from Graye-et-Charnay or Véria, which is exposed in the musée de l'Armée, shows the impact of a sword or spearhead in the area of the liver ${ }^{1}$ : an impressive example of the actual usage of the armour as such. Similar damage can be found on a slightly older cuirass from the Carpathian type cuirasses, which was found in the Danube at Pilismarót (fig. 2b). Here, the cuirass shows a $4 \mathrm{~cm}$ long impact above the right clavicle due to a stabbing weapon such as a sword.

Having access to the chemical analyses of Western European cuirasses, it was possible to note for some cuirasses an intentional addition of lead to the alloy compared to the Carpathian or Greek cuirasses, which contain less tin in the alloy. Unpublished pictures of the excavations of some of the Western European cuirasses gave valuable insights into the deposition practice, which is unknown for other cuirasses.

Western and Eastern European metal helmets differ significantly. While western European helmets are made of two bronze sheets joined together by rivets and folding one sheet over the other in the form of a crest, Eastern European helmets are made of one single bronze sheet forming the cap and a cast-on (rarely riveted on), central knob. These helmets developed out of organic boar tusk helmets, such as the one found in the afore mentioned Dendra grave. The western European helmets developed out of basic, rather massive cap helmets made of a single bronze sheet with a ridge or small crest from the forehead to the neck (fig. 3), which themselves developed out of organic material precursors. As for the cuirasses, the western European helmets, in particular helmets type Biebesheim (fig. 3), also show more signs of usage, damage, or weapon impact.

With the broad base of data, analyses, internal reports and publications (archaeological, material science and metallurgical) on Western European Bronze Age armour available at the C2RMF, in combination with the recently collected data on Eastern and Southern European armour, a complete study on European Bronze Age body armour was carried out, including detailed studies on manufacture techniques, as well as development, distribution and usage of the armour ${ }^{2}$.

\section{Acknowledgements}

The author would like to thank the Austrian Science Fund (FWF) and the FP7/Marie Curie actions who were supporting the research on European Bronze Age defensive armour with the Schrödinger-fellowship no. J 3109-G21. This research project has also been supported by the European Commission under the 7th Framework Programme through the Key Action: Cultural Heritage Advanced Research Infrastructures: Synergy for a Multidisciplinary Approach to Conservation/Restoration, Grant Agreement Nr. 228330-CHARISMA.
Notes

1. Mödlinger, 2014, fig. 28. 2. Mödlinger, 2014; Mödlinger, forthcoming.

\section{Bibliography}

Mödlinger M. (forthcoming). Protecting the body in war and combat: metal body armour in Bronze Age Europe. Oriental and European Archaeology (ÖAW: Wien).

Mödlinger M., 2014, "European Bronze Age Cuirasses: aspects of chronology, typology, manufacture and usage", Jahrbuch des Römisch-Germanischen Zentralmuseums 59 (2012), p. 1-50.
Mottier Y., 1988, „Die Bronzepanzer von Fillinges aus der späten Bronzezeit (800 v. Chr.)“, Helvetia archaeologica 76, p. 110-145.

Müller-Karpe H., 1980, Handbuch der Vorgeschichte 4. Bronzezeit (Beck: München).

Petres E. F., Jankovits K., 2014, „Der spätbronzezeitliche zweiteilige Bronzebrustpanzer aus der Donau in Ungarn“, Acta Archaeologia Hungarica 65/1, p. 43-71. 